\title{
Perunaviruksen aiheuttamat kustannukset siemenperunan tarjontaketjulle
}

\author{
Jussi Tuomisto \\ MTT Taloustutkimus, MTT Ylistaro, Alapääntie 104, 61400 YLISTARO jussi.tuomisto@mtt.fi
}

Tiivistelmä: Perunavirukset eivät aikaisemmin ole Suomessa aiheuttaneet kovin merkittäviä kustannuksia ja virusriskit ovat olleet pieniä. Viimeisen kahden vuoden aikana tilanne on nopeasti muuttunut ja perunan A- ja Y-virukset ovat aiheuttaneet siemenperunantuotannossa siemenperunaerien hylkäämisiä ja siemenperunaluokkien laskua. Samalla siemenperunaketju on lyhentynyt. Elintarviketurvallisuusviraston siementarkastusosaston mukaan vuonna 2006 yli puolessa testatuissa siemenperunoista löytyi virusta, joista $85 \%$ oli Y-virusta ja loput Avirusta. Viruksen takia hylättiin 10 siemenperunaviljelystä, noin 56 ha (3,2 \%) ja siemenluokka on laskenut joka kolmannella viljelyksellä. Siemenperunaluokkien aleneminen ja erien hylkääminen siemenperunaksi kelpaamattomana johtavat tilatasolla suuriin taloudellisiin menetyksiin ja lisäksi ne aiheuttavat yhteiskunnallisesti suuria hyvinvointitappioita.

Virusriskit nostivat siemenperunan tuotantokustannusta 8,27 senttiä/kg (17,8 \%) vuonna 2006. Viisisukupolvisessa siemenperunaketjussa muodostuu tuotantokustannukseksi 46,48 senttiä perunakiloa kohti. Silloin Suomen siemenperunan tarjontaketjun kokonaiskustannus on lähes 13,8 miljoonaa euroa. Tuotantoketjun lyhetessä neljään sukupolveen, pelkästään tuotantoketjun lyhenemisen takia, kokonaiskustannus nousee 780109 euroa, runsaaseen 14,5 miljoonaan euroon. Tällöin siemenperunan tuotantokustannus nousee 5,4 prosenttia, 49,12 senttiin siemenperunakiloa kohti. Kolmisukupolvisessa tuotantoketjussa siemenperunan tuotantokustannus on jo 55,77 senttiä/kg ja lisäkustannus koko tuotantoketjulle 2,8 miljoonaa euroa.

Virukset leviävät tehokkaasti kirvojen välityksellä. Siemenperunantuotannossa virusongelman lähtökohtana on korkeimpien siemenluokkien keskittyminen samalle suppealle alueelle, jossa viljellään myös alempia siemenluokkia ja virustarkastamatonta ruokaperunaa. Lisäksi vuonna 2002 Maa- ja metsätalousministeriön päätöksellä vapautettiin siemenperunakeskuksen tuotantoalueella (High Grade-alue) oman siemenen käytön mahdollisuus ruokaperunaa tuottavilla tiloilla. Tämä lisää virusten leviämispainetta siemenperunantuotantoalueella.

Siemenperunan puhtaus viruksista pitäisi varmistaa jo tuotantoketjun alkupäässä riittävän suurella otoskoolla, jotta tuotantoketjun myöhäisemmissäkin vaiheissa kyettäisiin tuottamaan asetetut enimmäisvirusmäärät alittavaa siementä. Elintarviketurvallisuusvirasto testaa siemenperunan virusten osalta laboratoriotestein. Testien otoskoot ovat kuitenkin liian pieniä korkeammissa siemenluokissa. Testaukseen otetaan jokaista siemenviljelystä kohti 200 siemenmukulaa, joista 100 tarkastetaan. Kymmenen aarin esiperussiemenviljelyksellä, jos oletettu virusmäärä olisi $0,1 \%$ ja otoksen tarkkuuden tavoitteena olisi päästä +-0,1 \% päähän estimaatista luottamustasolla 95 \%, otoskoon pitäisi olla $3502 \mathrm{kpl}$ mukuloita. Sadan mukulan otos riittää sertifioidun siemenen B-luokassa, jossa Y-viruspitoisuus saa olla enintään 10 \%. Keskeinen ongelma on myös perunoiden kerääminen virusnäytettä varten: perunavarasto on usein täytetty perunalaatikolla niin, että näyte kyetään keräämään vai reunimmaisista ja päällimmäisistä laatikoista, eikä siten edusta koko siemenerää. Näytteenotto pitäisi keskittää perunan sadonkorjuuhetkeen, jolloin näyte voitaisiin kerätä tasaisesti koko erästä.

Asiasanat: Perunavirus, siemenperuna, tarjontaketju, tuotantokustannus 


\section{Johdanto}

Perunavirukset eivät aikaisemmin ole Suomessa aiheuttaneet kovin merkittäviä kustannuksia ja virusriskit ovat olleet pieniä. Silti Perunan Y-virus on Elintarviketurvallisuusviraston (Evira) siementarkastus- ja luomuvalvontayksikön (SILU) tilastojen mukaan ollut syynä puolessa niistä tapauksista, joissa siemenperuna on hylätty siementarkastuksissa siemeneksi kelpaamattomana.

Viimeisen kahden vuoden aikana tilanne on nopeasti muuttunut ja perunan A- ja Yvirukset ovat aiheuttaneet Suomen siemenperunantuotannossa yhä enemmän siemenperunaerien hylkäämisiä ja korkeammiksi siemenluokiksi tarkoitetun siemenperunan alentumista alempiin siemenluokkiin. Samalla siemenperunaketju, korkeimmasta siemenluokasta, esiperussiemenestä, ruokaperunantuotannossa käytettävään sertifioidun siemeneen, on lyhentynyt. Samanlaisia ongelmia on esiintynyt myös muualla EU:n alueella, esimerkiksi Hollannissa ja Ruotsissa (Kortemaa 2006). Suomessa kirvalevintäiset, Y-, A-, Sja M-virukset, aiheuttavat suurimmat sato- ja laatutappiot, mutta myös maa-aineksen mukana leviävä maltokaarivirus (mop top) on Suomen ja Euroopan pohjoisten tuotantoalueiden vitsaus.

Perunan Y-virus leviää tehokkaasti kirvojen välityksellä. Kirvan koepisto lehteen riittää viruksen saamiseen ja uusi koepito toisen kasvin lehdellä viruksen tartuttamiseen. Virus ei kuitenkaan säily kirvan imukärsässä eli pistimessä (proboscis) tartuntakykyisenä kuin joitakin tunteja. Virus voi tällöin siirtyä kirvan mukana korkeintaan muutamia satoja metrejä. (Valkonen 2006). Alle 3 \%:n Y-virussaastunta siemenperunaerässä voi johtaa $70 \%$ saastuntaan sadossa jo ensimmäisenä viljelykesänä (Tiilikkala ym. 1988). Tiilikkalan ym. (1998) kokeissa sadon määrä ei vähentynyt ensimmäisenä lisäysvuotena, jona 70 \% sadosta sai virustartunnan. Seuraavana kasvukautena, jolloin siemenenä käytettiin ensimmäisen kesän satoa, sadon arvioitiin vähentyneen kolmanneksella.

Virukselle ei ole olemassa kemiallista torjuntakeinoa. Tehokkaimpia torjuntakeinoja kirvalevintäisiä viruksia vastaan ovat terve siemen, siemenperunaviljelysten pitäminen erillään muista perunapelloista, varsinkin kotitarvepalstoista sekä jäteperunakasojen hävittäminen. Siemenperunantuotanto on kuitenkin alueellisesti hyvin keskittynyttä (Tuomisto ym. 2006). Kun virusongelma on tullut siemenperunan tuotantoalueelle, sen eliminoiminen on hyvin vaikeaa ja kallista.

Tässä tutkimuksessa selvitetään mitkä ovat perunaviruksen aiheuttamat kustannukset siemenperunantuotannossa ja etsitään parannuskeinoja virusriskien vähentämiseksi.

\section{Aineisto ja menetelmät}

Tutkimuksen aineisto kerättiin Elintarviketurvallisuusviraston (Evira) siementarkastusosastolta (STO), joka testaa vuosittain perunavirukset kaikilta siemenperunaviljelyksiltä.

Kloonatusta siemenperunasta, ensimmäisestä esiperussiemenluokasta kyetään Suomessa lisäämään siemenperunaa keskimäärin 4,5 kertaa, ennen kuin se myydään siemeneksi ruokaperunantuottajalle. Tuotantoketju voisi olla pidempikin, jopa seitsenportainen. Virukset ovat merkittävin yksittäinen tekijä, jotka lyhentävät siemenperunan tuotantoketjua ja vähentävät siemenperunan monistettavuutta. Siemenkauppalaissa ja -asetuksissa on määrätty tietty enimmäismäärä, kuinka paljon saa eri siemenluokissa olla perunaviruksia. Taulukossa 1 on esitetty Suomessa käytettävät siemenperunaluokat ja niiden polveutuminen sekä eri siemenluokissa olevat enimmäismäärät A- ja Y-virusta. 


\begin{tabular}{|c|c|c|}
\hline Tuotantovaihe & Siemenluokka & Viruksia enintään \\
\hline \multicolumn{3}{|l|}{$\begin{array}{l}\text { Lajikkeiden puhdistus } \\
\text { taudeista }\end{array}$} \\
\hline \multicolumn{3}{|l|}{$\begin{array}{l}\text { Mikrolisäys, } \\
\text { mukulatuotanto } \\
\text { kasvihuoneessa }\end{array}$} \\
\hline $\begin{array}{l}\text { Esiperussiemenen } \\
\text { avomaatuotanto }\end{array}$ & S, SEE, SE & $0,2 \%$ \\
\hline \multirow{3}{*}{ Perussiemenen tuotanto } & E1, & $0,2 \%$ \\
\hline & E2 & $0,5 \%$ \\
\hline & E3 & $1,0 \%$ \\
\hline \multirow{2}{*}{$\begin{array}{l}\text { Sertifioidun siemenen } \\
\text { tuotanto (yksi sukupolvi: } \\
\text { joko A tai B) }\end{array}$} & A & $\begin{array}{c}4 \% \text {, josta Y-virusta } \\
\text { enintään } 2 \%\end{array}$ \\
\hline & B & $10 \%$ \\
\hline
\end{tabular}

Taulukko 1. Siemenperunan polveutuminen ja talvitestauksen (laboratoriotestaus) enimmäisviruspitoisuus eri siemenluokissa (Evira 2007)

Evira testaa Suomessa kaikki tuotetut siemenperunat ottamalla otoksen jokaisesta viljellystä siemenperunaerästä ja testaa virukset Elisa-testein. Otoskoko voidaan määrittää seuraavan kaavan perusteella. Kaava 1 osoittaa sopivan otoskoon laskennan tiettyjen rajaehtojen vallitessa.

$$
n=\frac{N p(1-p)}{(N-1)\left(d^{2} / z^{2}\right)+p(1-p)}
$$

Kaavan 4 mukaan otoskoon laskentaa varten tarvitaan seuraavat tiedot: $\boldsymbol{n}=$ otoskoko, $\boldsymbol{N}$ = kokonaismukulamäärä, josta näyte otetaan, $\boldsymbol{p}=$ viruksen oletettu esiintyvyys perunoissa (voidaan määritellä esitestauksella) $\boldsymbol{d}=$ etäisyys, jonka sisällä "oikean" esiintyvyyden halutaan olevan estimaatista luottamustasolla 1-alpha, $\mathbf{z}=$ normaalijakauman alpha/2 yläkvantiili. Jos alpha $=5 \%$ (= $95 \%$ luottamustaso $), z=1.96$ ja jos alpha $=10 \%(=90 \%$ luottamustaso), $\mathrm{z}=1.64$

Virusten aiheuttamia taloudellisia vaikutuksia ja niiden jakautumista siemenperunaketjussa arvioidaan maatalouden kannattavuuskirjanpitoaineiston pohjalta tehtyjen tilamallilaskelmien ja aikaisemmin tehtyjen kannattavuustutkimusten (mm. Tuomisto 2007) perusteella. Hyötyjen ja kustannusten jakautumista tarjontaketjun sisällä arvioitiin aikaisemmin tehdyn sopimustuotantotutkimuksen avulla (Tuomisto 2007).

Tilamallilaskelmat perustuvat tilakohtaisiin nettovoittolaskelmiin, jotka tehtiin keskikokoiselle 15 siemenperunahehtaarin tilalle. Laskelmien avulla arvioidaan, miten viruksista aiheutuvat kustannukset jakautuvat eri osapuolille. Tilakohtainen kannattavuus on laskettu nettovoittolaskelmien (2) avulla: 


$$
\pi_{A}=\frac{\sum_{t=1}^{T}\left(\sum_{i=1}^{n} p_{i} y_{i}-\sum_{j=1}^{m} w_{j} x_{j}+\sum_{k=1}^{z} s_{k}\right)}{T}
$$

Keskimääräinen pitkän aikavälin nettovoitto $\pi_{A}$ on kokonaistulon, kokonaiskustannusten ja kokonaistuen summat jaettuna tarkasteltavan ajanjakson vuosien lukumäärällä $\boldsymbol{T}$.

Virusriskit nostavat siemenperunan tuotantokustannusta ja markkinoilla siemenperunan hintaa. Pelkän siemenen kilohinnan mukaan ei voida määrittä istutettavan perunahehtaarin siemenkustannusta. Siemenen hinnan lisäksi hehtaarikustannukseen vaikuttavat siemenen kappalepaino ja vaadittava istutusetäisyys, jotka vaihtelevat lajikkeittain ja siemenkoon perusteella. Keskimääräinen siemenkustannus $\boldsymbol{C}_{\boldsymbol{R} i}$ (euroa/ha) on laskettu kertomalla kunkin lajikkeen ja siemenkoon vaatiman istutusetäisyyden $\boldsymbol{l}_{\boldsymbol{i}}(\mathrm{cm})$ ja tarhavälin $\boldsymbol{r}_{\boldsymbol{i}}(\mathrm{cm})$ perusteella määritetty tarvittava siemenmäärä $(\mathrm{kpl} / \mathrm{ha})$ siemenpainolla $\boldsymbol{z}_{\boldsymbol{i}}(\mathrm{g} / \mathrm{kpl})$ ja kertomalla tästä saatu tulo siemenen keskimääräisellä deflatoidulla siemenen myyntihinnalla $\boldsymbol{w}_{\text {it }}$ (senttiä/kg) ottaen huomioon eri vuosina tuotetun siemenen suhteellinen osuus $\boldsymbol{k}_{\boldsymbol{i t}}(\boldsymbol{k}=0, \ldots, 1$, s.e. $\boldsymbol{\Sigma} \boldsymbol{k}=1)$ eri siemenkokoluokissa $(\boldsymbol{i}=1 \ldots n)$ ja jakamalla tästä saadut summat tarkasteltavien vuosien $\boldsymbol{t}(\boldsymbol{t}=$ $1, \ldots, T)$ lukumäärällä $\mathbf{T}$ :

$$
C_{R i}=\frac{\sum_{t=1}^{T} \sum_{i=1}^{n} k_{i t} z_{i} \frac{10^{5}}{\alpha_{i} \beta_{i}} w_{i t}}{T}
$$

Perunavirusriskien aiheuttamat kustannukset koko siemenperunaketjulle on arvioitu summaamalla kunkin siemenperunaluokan tuotantokustannukset yhteen. Kaavassa 4 summa $\boldsymbol{V}$ ilmaisee Suomen koko siemenperunan tuotantoketjun arvon. Kaavassa $(\boldsymbol{i}=1 \ldots n)$ ilmaisee kunkin siemenluokan hehtaarikohtaiset tuotantokustannukset, $(\boldsymbol{j}=1 \ldots m)$ summaa yhteen kussakin siemenluokassa viljellyt hehtaarit ja $(\boldsymbol{h}=1 \ldots l)$ laskee yhteen kaikkien siemenluokkien kokonaiskustannukset

$$
V=\sum_{h=1}^{l} \sum_{j=1}^{m} \sum_{i=1}^{n} w_{i j} x_{i j}
$$

Tuotantokustannukset tuotettua siemenperunakiloa kohti alenevat kun tuotantoketju pitenee.

\section{Tulokset ja tulosten tarkastelu}

Eviran siementarkastusosasto hylkäsi vuonna 2005 viruspitoisuuden takia seitsemän siemenperunaerää (2,7 \%) ja 49 erässä (19,2 \%) siemenperuna laski viruksen takia alempaan siemenluokkaan. Vuonna 2006 virustilanne on vieläkin pahempi: yli puolessa testatuissa perunoista löytyi virusta, joista $85 \%$ oli Y-virusta ja loput A-virusta. Viruksen takia hylättiin 10 siemenperunaviljelystä, noin 56 ha (3,2 \%) ja siemenluokka on laskenut joka kolmannella viljelyksellä. Kuvassa 1 on esitetty virallisissa siementarkastuksissa perunaviruksen takia hylättyjen ja siemenluokissa alentuneiden siemenperunoiden suhteellinen osuus vuosina 1998-2006. 


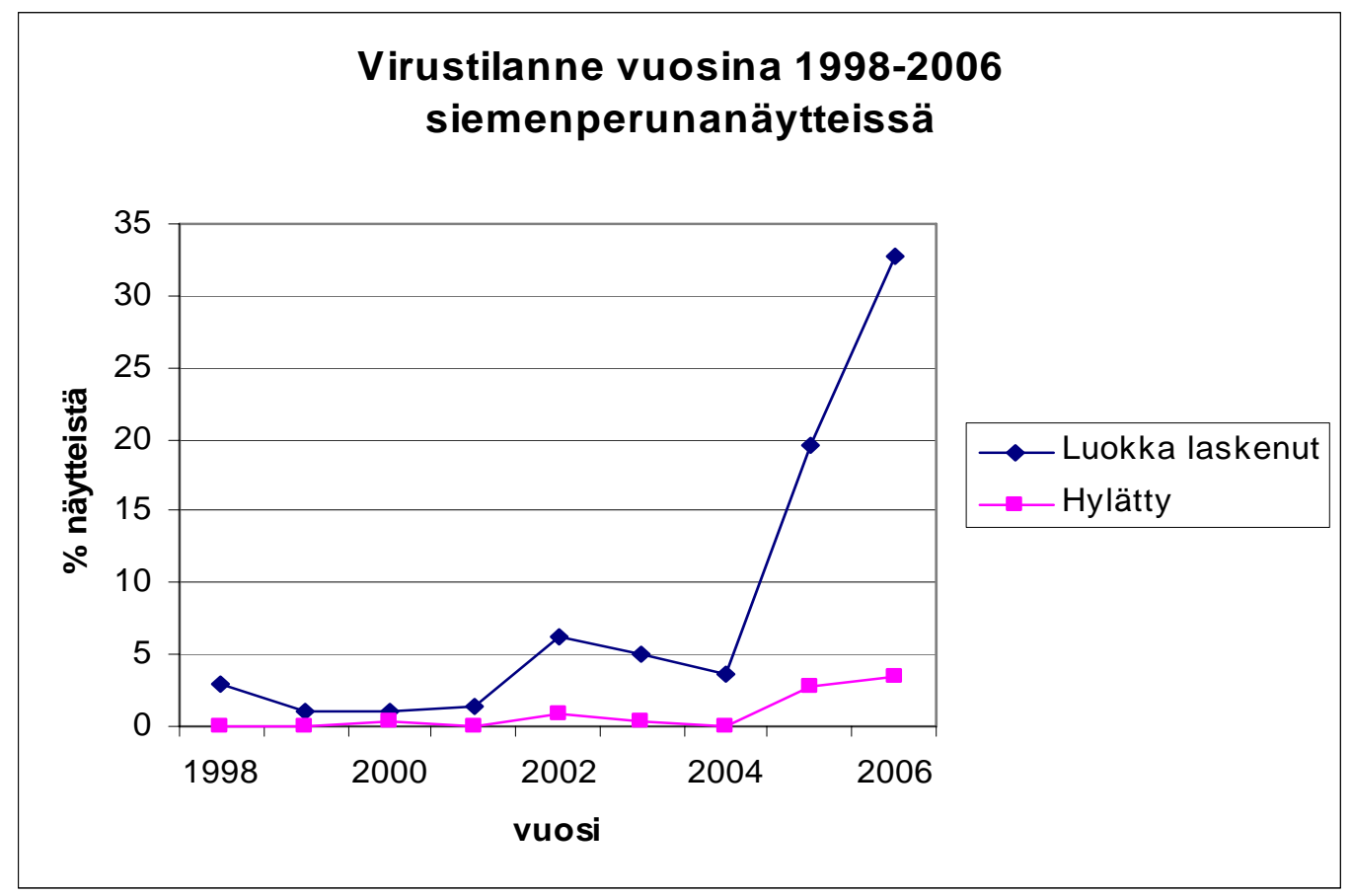

Kuva 1. Perunaviruksen takia tapahtuneet Siemenperunan hylkäämiset tai siemenluokan alenemiset vuosina 1998-2006 (Evira 2007)

Siemenperunaluokkien aleneminen ja erien hylkääminen siemenperunaksi kelpaamattomana johtavat tilatasolla suuriin taloudellisiin menetyksiin, mutta lisäksi ne aiheuttavat yhteiskunnallisesti suuria hyvinvointitappioita. Siemenperunatilalla pahin mahdollinen tilanne on, että siemenperuna ei virusten takia kelpaa siemeneksi ja se joudutaan myymään ruokaperunaksi siemenperunan tuotantokustannuksia alhaisemmalla hinnalla. Keskikokoisella 15 siemenperunahehtaarin tilalla se merkitsisi keskimäärin 49000 euron tulonmenetystä. Yksi siemenperunaerän hylkäys kerran viidessä vuodessa (20 \%:n hylkäysriski) aiheuttaisi sen, että siemenperunantuotannossa ei muodostuisi lainkaan pitkän aikavälin käyttökatetta ja tuotanto jouduttaisiin lopettamaan kannattamattomana. Siemenperunaluokan aleneminen A-luokasta B-siemenluokkaan aiheuttaisi 15 siemenperunahehtaarin tilalla keskimäärin 8900 euron tulonmenetyksen.

Vuonna 2005 virusriskit nostivat siemenperunan tuotantokustannusta 6,18 senttiä/kg (13,3 \%), ja 8,27 senttiä/kg (17,8 \%) vuonna 2006. Viisisukupolvisessa siemenperunaketjussa muodostuu tuotantokustannukseksi 46,48 senttiä perunakiloa kohti. Silloin siemenperunan tarjontaketjun kokonaiskustannus on lähes 13,8 miljoonaa euroa. Tuotantoketjun lyhetessä neljään sukupolveen, pelkästään tuotantoketjun lyhenemisestä johtuva kokonaiskustannus nousee 780109 euroa, runsaaseen 14,5 miljoonaan euroon. Tällöin siemenperunan tuotantokustannus nousee 5,4 \%, 49,12 senttiin siemenperunakiloa kohti. Kolmisukupolvisessa tuotantoketjussa siemenperunan tuotantokustannus on jo 55,77 senttiä/kg ja lisäkustannus koko tuotantoketjulle 2,8 miljoonaa euroa. Kuva 2 osoittaa siemensukupolvien määrän vaikutuksen siemenperunan tuotantokustannukseen sekä viruksen aiheuttaman lisäkustannuksen koko perunaketjulle silloin kun viruksen takia perunan tuotantoketju lyhenee. 




Kuva 2. Siemenperunasukupolvien vähenemisen vaikutus siemenperunan tuotantokustannukseen ja koko siemenperunaketjun lisäkustannuksiin

\section{Johtopäätökset}

Virukset leviävät tehokkaasti kirvojen välityksellä. Kun virusongelma on tullut Suomen siemenperunan tuotantoalueelle, sen eliminoiminen tulee vaikeaksi ja kalliiksi. Virusongelma aiheuttaa tilakohtaisia tuotannon riskejä, yhteiskunnallista hyvinvointitappiota ja vaikeuttaa kotimaisen siemenperunan kilpailukykyä.

Siemenperunantuotannossa virusongelman lähtökohtana on korkeimpien siemenluokkien keskittyminen samalle suppealle alueelle, jossa viljellään myös alempia siemenluokkia ja virustarkastamatonta ruokaperunaa. Ongelman yhdeksi lähtökohdaksi voidaan mainita vuonna 2002 annettu Maa- ja metsätalousministeriön päätös, joka vapautti korkealaatuisen siemenperunan tuotantoalueella (High Grade-alue) vuodesta 2003 lähtien oman, virustarkastamattoman siemenen käytön mahdollisuuden ruokaperunaa tuottavilla tiloilla (MMM 2002) Siitä lähtien on kirvalevintäisten virusten määrä nopeasti lisääntynyt siementuotannossa. Sertifioidun siemenen käyttövelvoitteen palauttaminen korkealaatuisen siemenperunan tuotantoalueelle olisi ensiarvoisen tärkeää.

Herkästi leviävien virusten osalta omakotipalstat ovat myös merkittävä riskitekijä, koska viruksia esiintyy niillä yleisesti (Pohto 2002).

Siemenperunan puhtaus viruksista pitäisi varmistaa jo tuotantoketjun alkupäässä riittävän suurella otoskoolla, jotta tuotantoketjun myöhäisemmissäkin vaiheissa kyettäisiin tuottamaan asetetut enimmäisvirusmäärät alittavaa siementä. Elintarviketurvallisuusvirasto testaa siemenperunan virusten osalta laboratoriotestein. Testien otoskoot ovat kuitenkin liian pieniä korkeammissa siemenluokissa. Testaukseen otetaan jokaista siemenviljelystä kohti 200 siemenmukulaa, joista 100 tarkastetaan. Kymmenen aarin esiperussiemenviljelyksellä, jos oletettu virusmäärä olisi 0,1 prosenttia ja otoksen tavoitteena olisi päästä +-0,1 prosenttiyksikön tarkkuuteen 95 prosentin luottamustasolla, otoskoon pitäisi olla 3502 kpl 
mukuloita. Sadan mukulan otos riittää sertifioidun siemenen B-luokassa, jossa Yviruspitoisuus saa olla enintään $10 \%$.

Keskeinen ongelma on myös perunoiden kerääminen virusnäytettä varten: perunavarasto on usein täytetty perunalaatikolla niin, että näyte kyetään keräämään vai reunimmaisista ja päällimmäisistä laatikoista, eikä siten edusta koko siemenerää. Tärkeää olisi että näytteenotto voitaisiin keskittää perunan sadonkorjuuhetkeen, jolloin näyte voitaisiin kerätä tasaisesti koko erästä.

\section{Kirjallisuus}

Kortemaa, H. 2006 Virukset siemenperunassa. Tuottava Peruna, Perunantutkimuslaitoksen (PETLA) julkaisu 1/2006 s. $10-11$

MMM, 2002. Perunantuotannon tukijärjestelmän kehittäminen - työryhmän raportti 30.6.2002 Maa- ja metsätalousministeriö. $31 \mathrm{~s}$.

Pohto, A. 2002. Korkealaatuisen siemenperunan tuotantoalueen erityisasema ja merkitys. Maa- ja metsätalousministeriön julkaisuja 11/2002. 33 s.

Tiilikkala, K \& Kurppa, A. 1988. Bekämpning av potatis virus Y (PVY) infektion med oljebespruting. Sveriges lantbruksuniversitet. Växtskyddasraportter. Jordbruk 53: 93-97.

Tuomisto, J. 2007 Contract production as a method to reduce welfare loss caused by market uncertainty of seed potato, Agricultural and Food Science vol. 16. p. 3-16, 2007.

Tuomisto, J \& Huitu, H. 2006. Reducing costs caused by isolation requirements between GM and non-GM potato fields - a method based on GIS. Paper presented of 10th ICABR conference: Facts, Analysis and Policies Ravello (Italy) June 29 - July 2, 2006. 37 p.

Abstract available: http://www.economia.uniroma2.it/conferenze/icabr2006/abstract/

Valkonen J. 2006. Kirvalevinnäiset virukset siemenperunassa. Tuottava Peruna, Perunantutkimuslaitoksen (PETLA) julkaisu 2/2006 s. 9-11. 